\title{
DNA barcoding to resolve phylogenetic relationship in Myristica spp.
}

\author{
V P Swetha ${ }^{1,2}$, T E Sheeja ${ }^{1} \&$ B Sasikumar ${ }^{1, *, \#}$ \\ ${ }^{1}$ Division of Crop Improvement and Biotechnology, \\ ICAR-Indian Institute of Spices Research, Kozhikode-673 012, Kerala. \\ ${ }^{2}$ University of Calicut, Kozhikode, Kerala. \\ ${ }^{\text {\#Former Head }}$ \\ *E-mail: sasikumarsooranadu@gmail.com
}

Received 08 April 2019; Revised 13 September 2019; Accepted 23 September 2019

\begin{abstract}
Myristica is the largest and primitive genus of the taxonomically complex family Myristicaceae. DNA barcoding was used to study the evolutionary relationship between Myristica spp. and other genera of Myristicaceae. The barcoding loci namely, rbcL, matK, $p s b A-t r n H$, ITS and multilocus combinations were tested to assess their phylogenetic relationship. $p s b A-t r n H$ locus revealed information regarding the relationship of species in Myristica genus. M. fragrans was found to be closely related to M. beddomei, M. amygdalina, M. andamanica1, whereas M. fatua was found to be distinct from M. malabarica. Gymnocranthera and Knema species were found to share sister relation with other Myristica spp.
\end{abstract}

Keywords: barcoding, evolution, Myristica, multilocus, nutmeg, phylogram

\section{Introduction}

Myristica is the largest and most primitive genus of Myristicaceae family (Sinclair 1958) that has around 18 genera and 300 species. New Guinea is considered as its centre of origin and distribution of Myristica genus (http://www. fao.org/docrep/x5047E/x5047E04.htm). They are pantropical and are seen in the rainforests of Asia, Africa, Madagascar, South America and Polynesia (Krishnamoorthy et al. 2007). Blume and Bentham divided the genus into four sections viz., Knema, Irya, Pyrrhosa and Eumyristica according to their androecium modifications (Hooker \& Thomson 1855) while
Hooker (1856) classified it into three sections Knema, Myristica and Pyrrhosa.

Presently four genera of Myristicaceae are found in India - Myristica, Horsfieldia, Knema and Gymnocranthera, mostly in Andaman and Nicobar Islands as well as in Myristica swamps found in valleys of Kulathupuzha, Shendurney, and forest ranges of Anchalin, South Western Ghats and the district Uttara Kannada of Central Western Ghats of India (Krishnamoorthy et al. 2007). There are about 120 species of Myristica, of which, 14 are found in India. Myristica genus is represented by species like Myristica fragrans Houtt., M. malabarica Lam., M. andamanica 
Hook.f., M. fatua Houtt., M. beddomei King and M. prainii King (Krishnamoorthy et al. 2007), of which $M$. fragrans is the most important and commercially cultivated one (Bose et al. 2008). The seed and mace of $M$. fragrans (nutmeg) is widely used as a spice and in medicine, while mace of $M$. malabarica is exploited as a dye source. Other economically important species of Myristica genus are $M$. andamanica and $M$. beddomei, which are used in traditional medicine (Zachariah et al. 2008; Arunachalam \& Subhashini 2011; Manjunatha et al. 2011). The wood of M. beddomei and M. malabarica is also used in making match boxes and splints (Sastri 1962; Bose et al. 2008). Inspite of the economic potential of the genus, the phylogeny and taxonomy of the genus are poorly understood.

Morphological characters are given dominance while studying phylogeny. But some of the inherent problems such as plasticity in phenotypic characters and variation in genotypic characters, interaction of the genotype with the environment, cryptic taxon and difficulty in finding reliable characters because of variation in expression or long maturity periods or incomplete penetrance reduce the reliability of morphological characters in phylogenetic studies (Abeysinghe et al. 2009).

Presently DNA barcoding, a technique based on the sequence variation in certain nucleotide sequences called barcodes has come up as a tool for molecular taxonomy (Hebert et al. 2003). In plants, the chloroplast genes like $r b c L$ (coding for large subunit of RUBISCO), matK (coding for maturase), $p s b A-t r n H$ and nuclear Internal Transcribed Spacer (ITS) regions serve as barcodes. The chloroplast DNA is considered as an informative phylogenetic marker for land plants (Bieniek et al. 2015). The predominant maternal inheritance and the conserved nature of chloroplast DNA have enhanced its application in evolutionary and phylogenetic studies (Schilling 1997; Mukherjee \& Bhat 2013). Here an attempt is made to study the relationships within Myristica species and between Myristica, Gymnocranthera and Knema genera using chloroplast regions and nuclear ITS region.

\section{Materials and methods}

\section{Collection of samples}

Leaves were collected from 18 accessions representing six species of genus Myristica, one species each of the genus Knema and genus Gymnocranthera from different locations in India (Table 1).

\section{DNA Isolation}

Total genomic DNA was isolated from all the leaf samples collected from plant species given in Table 1 using the procedure for nutmeg leaf DNA isolation (Sheeja et al. 2008). The qualitative and quantitative estimation of the isolated DNA was done by measuring the absorbances at 260 $\mathrm{nm}$ and $280 \mathrm{~nm}$ in a Biophotometer (Eppendorf, Germany).

\section{Amplification and sequencing of barcoding loci}

Genomic DNA was amplified using the universal barcoding loci primers of $r b c L$, matK, psbA-trnH and Internal Transcribed Spacer (ITS) synthesized by Integrated DNA Technologies (IDT) (USA) (Table 2). The reaction mixture composition of all loci was optimized and was carried out in $50 \mu \mathrm{l}$ reaction volume. The reaction mixture composition and the PCR reaction were performed as described by Swetha et al. (2017). The amplicons were purified using QIA quick PCR Purification kit (Qiagen, Germany) following the manufacturer's protocol. The purified products were sequenced bidirectionally at the DNA sequencing unit of SciGenome Labs Pvt Ltd (Cochin) Kerala.

Data analysis and submission of sequences to GenBank

The forward and reverse sequences obtained were assembled by the Cap 3 software (Huang \& Madan 1999) to generate their consensus sequences and were checked against the 
Table 1. Details of Myristica spp. used in the study

\begin{tabular}{|c|c|c|}
\hline Species & No. of accession & Place of collection \\
\hline M. fragrans Houtt. & $\begin{array}{l}3 \\
1 \\
1\end{array}$ & $\begin{array}{l}\text { IISR Experimental Farm, Peruvannamuzhi, } \\
\text { Kozhikode, Kerala, India. } \\
\text { Nagercoil, Tamil Nadu, India. } \\
\text { Andaman and Nicobar Islands, India. }\end{array}$ \\
\hline M. malabarica Lam. & $\begin{array}{l}1 \\
1 \\
1 \\
1 \\
1\end{array}$ & $\begin{array}{l}\text { IISR Experimental Farm, Peruvannamuzhi, } \\
\text { Kozhikode, Kerala, India. } \\
\text { Community Agro Biodiversity Center, } \\
\text { Wayanad, Kerala, India. } \\
\text { Nagercoil, Tamil Nadu, India. } \\
\text { Ernakulam, Kerala, India. } \\
\text { Kerala Forest Research Institute, Thrissur, } \\
\text { Kerala, India. }\end{array}$ \\
\hline M. andamanica Hook.f. & $\begin{array}{l}1 \\
1\end{array}$ & $\begin{array}{l}\text { IISR Experimental Farm, Peruvannamuzhi, } \\
\text { Kozhikode, Kerala, India. } \\
\text { Andaman and Nicobar Islands, India. }\end{array}$ \\
\hline $\begin{array}{l}\text { M. fatua Houtt. var. magnifica } \\
\text { (Bedd.) Sinclair }\end{array}$ & $\begin{array}{l}1 \\
1\end{array}$ & $\begin{array}{l}\text { IISR Experimental Farm, Peruvannamuzhi, } \\
\text { Kozhikode, Kerala, India. } \\
\text { Kerala Forest Research Institute, Thrissur, } \\
\text { Kerala, India. }\end{array}$ \\
\hline M. amygdalina (Wall.) Warb. & 1 & $\begin{array}{l}\text { IISR Experimental Farm, Peruvannamuzhi, } \\
\text { Kozhikode, Kerala, India. }\end{array}$ \\
\hline M. beddomei King & $\begin{array}{l}1 \\
1 \\
1\end{array}$ & $\begin{array}{l}\text { IISR Experimental Farm, Peruvannamuzhi, } \\
\text { Kozhikode, Kerala, India. } \\
\text { Ernakulam, Kerala, India. } \\
\text { Kerala Forest Research Institute, Thrissur, } \\
\text { Kerala, India. }\end{array}$ \\
\hline $\begin{array}{l}\text { Knema attenuata (Hook. f. \& } \\
\text { Th.) Warb. }\end{array}$ & 1 & $\begin{array}{l}\text { Kerala Forest Research Institute, Thrissur, } \\
\text { Kerala, India. }\end{array}$ \\
\hline $\begin{array}{l}\text { Gymnocranthera farquhariana } \\
\text { (Hook. f. \& Th.) Warb. }\end{array}$ & 1 & $\begin{array}{l}\text { Kerala Forest Research Institute, Thrissur, } \\
\text { Kerala, India. }\end{array}$ \\
\hline
\end{tabular}

Table 2. Primers employed for amplification of barcoding loci

\begin{tabular}{lll}
\hline $\begin{array}{c}\text { Primer } \\
\text { name }\end{array}$ & \multicolumn{1}{c}{ Sequence $\left(5^{\prime}-3^{\prime}\right)$} & \multicolumn{1}{c}{ Reference } \\
\hline $\begin{array}{l}\text { rbcLaf } \\
r b c L a r\end{array}$ & 5' ATG TCA CCA CAA ACA GAG ACT AAA GC 3' & Kress \& Erickson 2007 \\
matK 3F & 5' CGT ACA TCA AGT CCA CCG CG 3' & \\
matK $1 \mathrm{R}$ & 5' ACC CAG TCC ATC TGG AAA TCT TGG TTC 3' & Vijayan \& Tsou 2010 \\
$p s b A \mathrm{f}$ & 5'GTT ATG CAT GAA CGT AAT GCTC 3' & Yang et al. 2011 \\
trnH R & 5'CGT AAC AAG GTT TCC GTA GGT GAA 3' & \\
\hline
\end{tabular}


GenBank database of NCBI to confirm the species identity using the BLAST tool (Altschul et al. 1997). rbcL and matK sequences obtained for the coding loci were translated by employing ExPASY translate tool (Gasteiger et al. 2003) and their identity was checked using Protein BLAST tool. The nucleotide sequences obtained were deposited in the GenBank nucleotide database (Table 3).

Phylogenetic analysis

In addition to the amplified Myristica sequences, sequences that showed an e-value of zero on BLAST analysis for each locus was also included for phylogenetic analysis in order to give a better picture regarding the phylogenetic power of the selected barcoding loci. Magnolia acuminata was selected as the outgroup for the phylogenetic analysis based on a previous study in Myristica species (Sheeja et al. 2014). Single locus ( $r b c L$, matK and $p s b A$-trnH) and multi locus barcode $(r b c L+$ $m a t K, r b c L+t r n H-p s b A, m a t K+t r n H-p s b A$ and $r b c L+m a t K+t r n H-p s b A)$ approaches were tried for phylogenetic studies. The sequences were aligned using MUSCLE algorithm (Edger 2004) and manually trimmed using BioEdit software (Hall 1999). Multilocus barcodes were created for those loci that generated sequences for all loci by concatenating the sequence alignment files into one with FAScon CATv1.0 tool (Kück \& Longo 2014). The evolutionary history was inferred using the Bayesian analysis, performed in MrBayes version 3.1 (Ronquist \& Huelsenbeck 2003). Bootstrap analysis was performed with 10,000 replicates. All positions containing gaps and missing data were eliminated.

\section{Results and discussion}

Genomic DNA of high quality was obtained from the fresh leaves of Myristica species with yield in the range of 135 to $271 \mu^{-1} \mathrm{~g} \mathrm{~g}^{-1}$ and purity ratio (A260/A280) in the range 1.8 to 1.9. A good amplification success was obtained for $r b c L$, matK, ITS and $p s b A$-trnH loci with amplicons of size 600, 900, 750 and 450 bp (Fig. 1) respectively. High amplification success of these loci was
Table 3. GenBank accession numbers obtained for Myristica spp.

\begin{tabular}{cccc}
\hline Species & \multicolumn{3}{c}{ Accession Number } \\
\cline { 2 - 4 } & rbcL & psbA-trnH & matK \\
\hline M. fragrans 1 & KT367808 & KY966347 & KT367809 \\
M. fragrans 2 & KT380141 & KY966348 & KT380142 \\
M. fragrans 3 & KT445277 & KY966349 & KT445278 \\
M. fragrans 4 & KY945257 & KY966350 & MF547523 \\
M. fragrans 5 & KY945258 & KY966351 & MF547524 \\
M. malabarica 1 & KY945259 & KY966342 & MF547530 \\
M. malabarica 2 & KY945260 & KY966343 & MF547531 \\
M. malabarica 3 & KY945261 & KY966344 & MF547532 \\
M. malabarica 4 & KY945262 & KY966345 & MF547533 \\
M. malabarica 5 & KY945263 & KY966346 & MF547534 \\
M. andamanica 1 & MF158638 & MF086596 & MF547528 \\
M. andamanica 2 & MF158639 & MF086597 & MF547529 \\
M. fatua 1 & MF186596 & MF086592 & MF547525 \\
G. farquhariana 2 & MF5186597 & MF086593 & MF547526 \\
M. amygdalina & MF417801 & MF086598 & MF547527 \\
M. beddomei 1 & MF186599 & MF086594 & MF547536 \\
M. beddomei 2 & MF186600 & - & MF547537 \\
\hline
\end{tabular}

previously reported (Kress et al. 2005; Li et al. 2012; Zhang et al. 2015; Kumar \& Yusuf 2016).

Hundred per cent sequencing success was obtained for $r b c L$, matK and psbA-trnH. But for ITS, the forward and reverse reads could not be assembled in to contigs due to poor sequence quality. Sequencing failure of ITS has been reported previously in various works (Liu et al. 2012; Li et al. 2014; Bhagwat et al. 2015). Hollingsworth (2011) has reported that ITS may be present in numerous copies owing to incomplete concerted evolution and the multiple copies may be getting sequenced simultaneously, resulting in messy data that could not be processed further. 
The sequence length range obtained for $r b c L$, matK and psbA-trnH was 510 bp - 579 bp, 695 bp - 782 bp and 299 bp - 413 bp, respectively. BLAST analysis of the contigs obtained for matK, rbcL and $p s b A$-trnH exhibited maximum similarity to sequences of the respective locus of genus Myristica and other genera of family Myristicaceae. Protein BLAST done on the translated sequences of matK and $r b c L$ exhibited maximum similiarity to maturase and RUBISCO sequences of Myristicaceae family. The generated sequences were deposited in the nucleotide database GenBank (Table 3).

Sequences of individual locus namely, $r b c L$, matK, $p s b A-t r n H$ and concatenated sequences of multilocus combinations namely, $r b c L+m a t K$, $r b c L+p s b A-\operatorname{trn} H$, matK $+p s b A-\operatorname{trn} H$ and $r b c L+m a t K+p s b A-t r n H$ obtained were aligned and trimmed to uniform size. Sequences downloaded from GenBank database of NCBI were also included in the phylogenetic analysis of individual loci. rbcL sequences taken from GenBank are $M$. fragrans (AF206798), $M$. fragrans (AY298839), M. fatua (GQ248653), Myristica cf. sepicana (FJ976152), Myristica globosa (KF496610), Staudtia kamerunensis (KC628429), S. kamerunensis (KC628405), Compsoneura mexicana (EU090522) Horsefieldia amygdalina (KR529436) and H. amygdalina (KR529434). matK sequences taken from GenBank are $M$. fragrans (AJ966803), M. fragrans (EU669472), M. fatua (GQ248165), Myristica maingayi (DQ401374), M. maingayi (AY220452), Myristica yunnanensis (KR531264), M. yunnanensis (KR531265), Myristica cinnamomea (KJ709010), M. cinnamomea (KJ709009), Compsoneura preussii (AY743475), C. preussii (KC685082), Knema globularia (AB924720) and K. globularia (AB924868).psbAtrnH sequences taken from GenBank are $M$. fragrans (KT758178), M. fatua (GQ248350), M. globosa (GQ248351), M. yunnanensis (KR533281), M. yunnanensis (KR533282), H. amygdalina (KR533273), H. amygdalina (KR533274), S. kamerunensis (KC667945), C. preussii (KC688793) and C. preussii (KC688811).

Phylograms were constructed using single locus and multilocus combinations. The phylogenetic relationships between the Myristica species was studied using theindividual $(r b c L$, matKand $p s b A$ $\operatorname{trnH})$ and concatenated ( $r b c L+m a t K, m a t K+p s b A-$ trnH, rbcL+psbA-trnH, rbcL+matK+psbA-trnH) sequences with an outgroup using Bayesian inference (BI) methods. rbcL \& matK phylograms were drawn using a final alignment of $474 \mathrm{bp}$ and $688 \mathrm{bp}$, respectively. The phylograms obtained were rooted with $M$. acuminata, separated from the inner group. These phylograms were not able to provide any information regarding the phylogeny or discrimination of Myristica spp. The trees exhibited polytomy for the ingroup section. Difficulty of $r b c L \mathcal{E}$ matK loci in resolving closely related species was previously reported by Gielly \& Taberlet (1994) and Tallei et al. (2015).

$p s b A$-trnH phylogram was drawn using $p s b A$ trnH sequences with a final alignment of 281 bp (Fig. 2). This locus was able to reveal the relationship between Myristica species. In $p s b A-\operatorname{trn} H$ phylogram, M. andamanica, $K$. attenuata and $G$. farquhariana were found to be closely related. $M$. fragrans and $M$. malabarica appeared in separate clusters pointing to the distant relationship between them. M. beddomei, $M$. amygdalina, $M$. fatua and $M$. andamanica 1 collected from the same habitat were found to have close association with each other. Sequences of other genera formed monophyletic groups and appeared to be sister groups of Myristica spp. The utility of $p s b A-t r n H$ in discriminating plant species of different tree genera like Alnus (Ren et al. 2010) and Quercus (Simeone et al. 2013) have been previously reported.

The $m a t K+r b c L$ phylogram was drawn using the concatenated $r b c L$ and matK sequences. The data set contained 20 sequences trimmed to a final alignment of $1413 \mathrm{bp}$ that was used to generate a phylogenetic tree (Fig. 3). The rbcL+matK phylogram was rooted with $M$. acuminata that branched separately from the inner group. High bootstrap support was obtained for the nodes but different accessions of the same species were seen in different clades. $r b c L+m a t K$ phylogram showed close relation between $M$. beddomei, $M$. fatua and $M$. andamanica1. It showed the close association of $M$. andamanica2, K. attenuata and G. farquhariana. But this tree could not resolve 


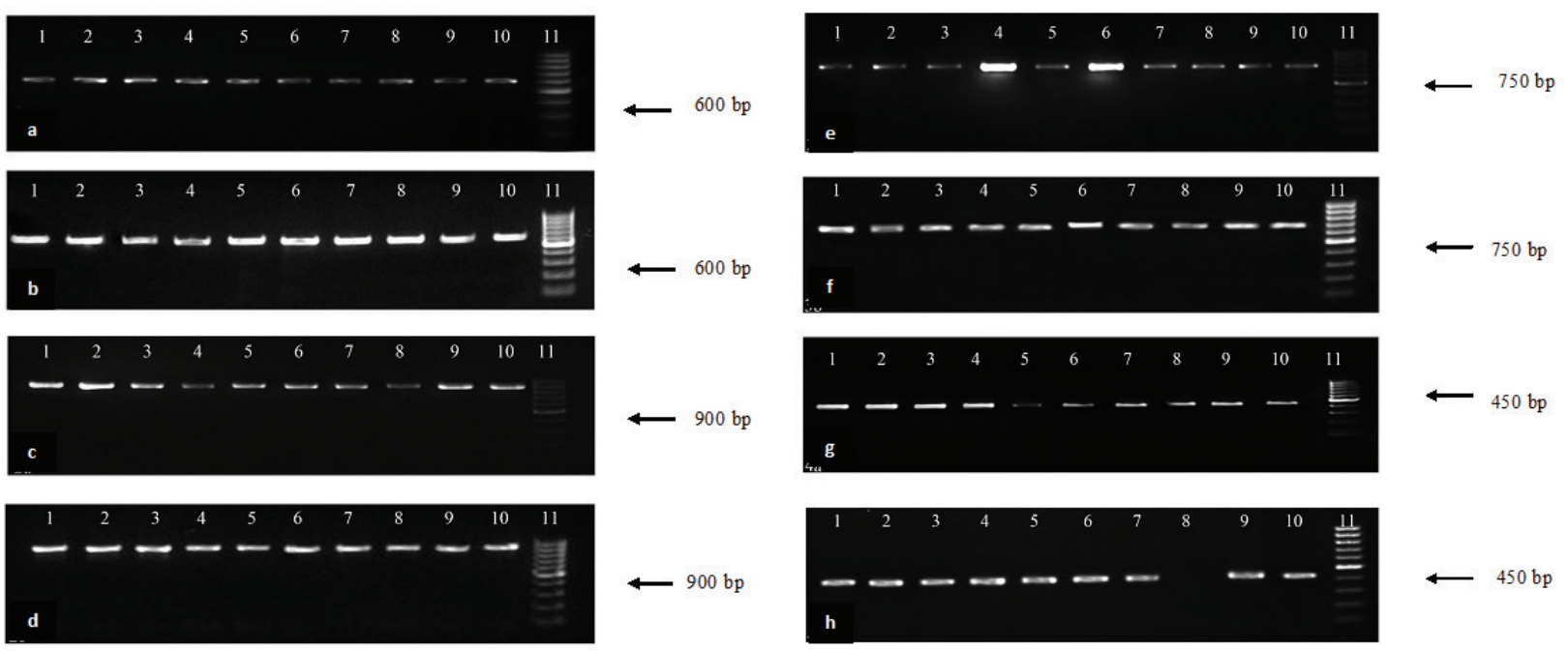

Fig. 1. Amplification of $r b c L(a, b)$, matK (c, d), ITS (e, f) and $p s b A-t r n H(g, h)$ loci in different Myristica accessions. Lane 1-5 and 6-10 in (a, c, e, g) was loaded with $M$. fragrans and M. malabarica, respectively. Lane $1-2 ; 3-4 ; 5 ; 6-8 ; 9$ and 10 in (b, d, f, h) is loaded with M. andamanica, M. fatua, M. amygdalina, M. beddomei, Knema attenuata and Gymnocranthera farquhariana, respectively, lane 11 in both (a) and (b): 100 bp ladder (Fermentas)

M. fragrans, M. amygdalina and M. malabarica. Though $r b c L+m a t K$ combination was proposed as ideal for plant species discrimination by Consortium for the Barcode of Life Plant Working Group, it failed to resolve Myristica spp. The failure of this combination in phylogenetic analysis has been previously reported by Li et al. (2014) in Calligonum species.

The topology of $r b c L+p s b A-t r n H$ tree (Fig. 4) was similar to $p s b A-t r n H, m a t K+p s b A-t r n H$ and $r b c L+m a t K+p s b A-t r n H$ trees except for a single sample of $M$. malabarica positioned outside the M. malabarica cluster. That distinct specimen of M. malabarica was collected from Nagercoil, Tamil Nadu while rest of the samples were collected from Kerala. Geographical separation may be the reason for its positioning outside $M$. malabarica cluster. In these trees, $M$. andamanica 1 collected from Andamans and M. andamanica2 collected from Kerala were also placed in different clades and showed close relation with different species which may also be due to geographical separation. Schneider et al. (2015) reported that genetic differences between species may be caused due to geographical separation. The accumulation of genetic differences by geographical isolation may have arisen in the process of adapting to different environmental conditions (Souframanien \& Gopalakrishnan 2004). A close relation was observed between $M$. beddomei, M. amygdalina, M. andamanica1 and $M$. fatua in the present study. This is in agreement with the earlier study conducted by Sheeja et al. (2014) on Myristicaceae; the phylogenetic analysis done using $18 \mathrm{~S}$ rDNA sequences that depicted the close relationship between $M$. beddomei, M. andamanica, M. amygdalina and their closeness was explained on the basis of the similarity in their seed and mace characters. $M$. fragrans was found to be closely related to $M$. beddomei, M. amygdalina, M. andamanica1 and $M$. fatua and distinct from M. malabarica. The close association between $M$. fragrans and the other species could be perhaps indicative of their common ancestry. $M$. fragrans and $M$. malabarica were clustered in two distinct clades due to the sequence divergence in $p s b A$-trn $H$ between these two species. Gymnocranthera and Knema species formed a sister clade within Myristica cluster. The sister relationship between Knema and Myristica was reported by Sauquet et al. (2003). Gymnocranthera, Knema and Myristica are Asian genera of Myristicaceae family. Clustering of Gymnocranthera and Knema along with Myristica may be due to the monophyly of the Asian genera of Myristicaceae (Sauquet et al. 2003). 


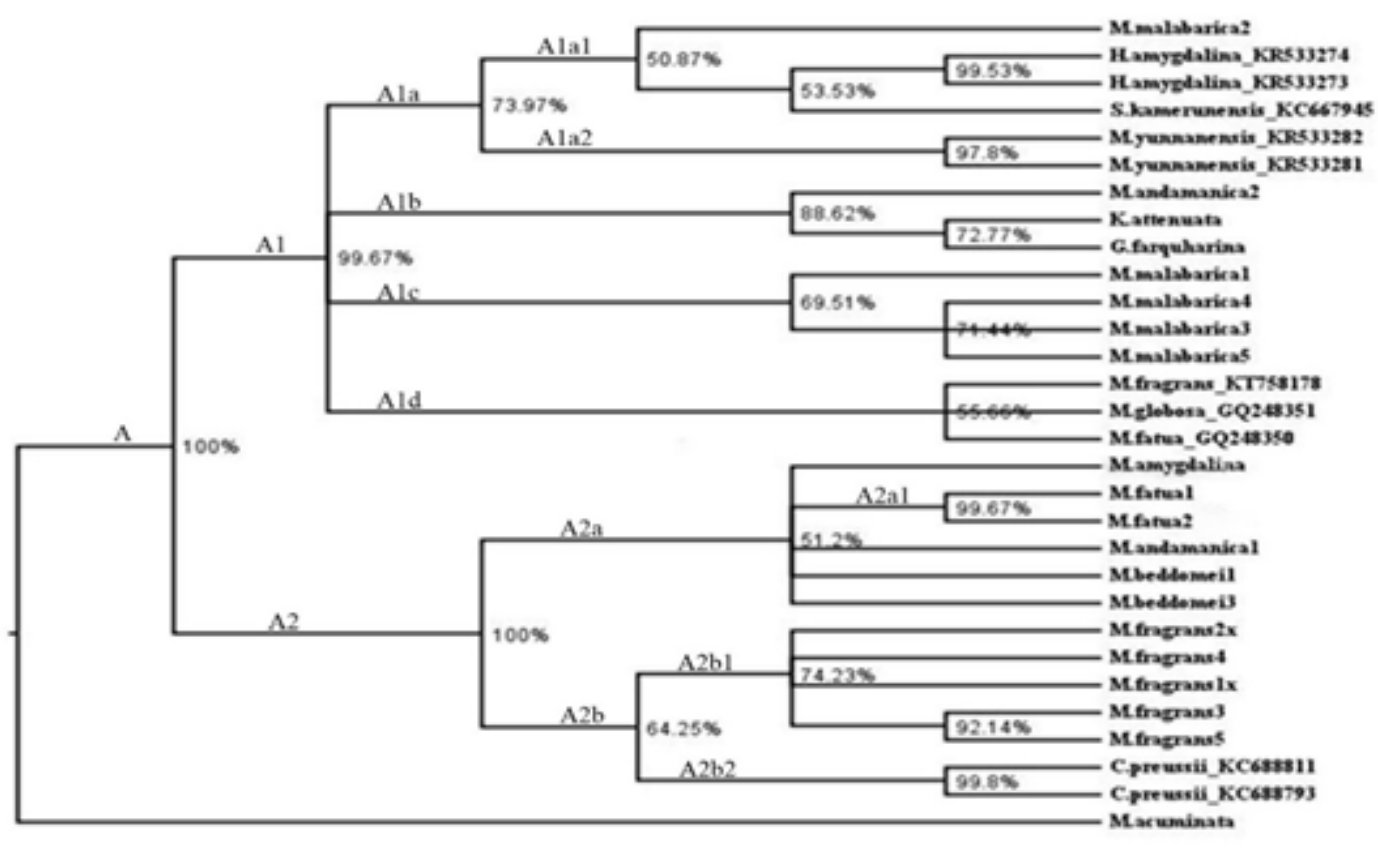

Fig. 2. Bayesian̄pohylogram for $p s b A-\operatorname{trn} H$ sequences

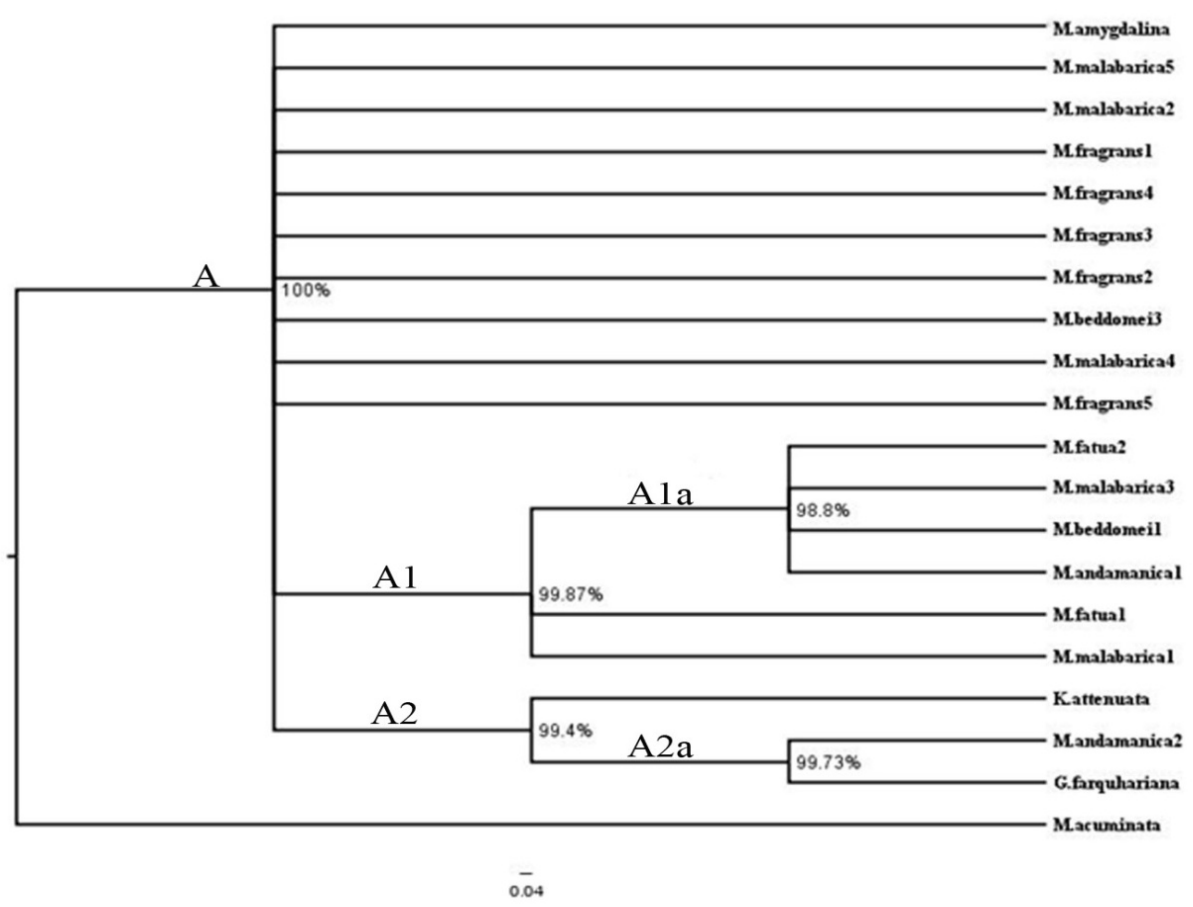

Fig. 3. Bayesian phylogram for $r b c L+$ matK sequences 




Fig. 4. Bayesian phylogram for $r b c L+p s b A-t r n H$ sequences

The results of the present study gave an insight on the genetic relationship among the members of Myristica genus. The locus psbA-trnH with its high sequence divergence provided information regarding the interspecific relation between species within the genus Myristica. Among the barcoding loci studied, only the locus $p s b A-t r n H$ was informative to elucidate the relationships amongst the members of the family.

\section{Acknowledgements}

We express our gratitude to the Director, ICARIISR for the facilities to carry out the study. Our heartfelt gratitude to Dr. K V Saji, Principal Scientist, ICAR-IISR and Dr. K Abhirami, Scientist, ICAR-Central Island Agricultural Research Institute for helping us in sample collection.

\section{References}

Abeysinghe P D, Wijhesinghe K G G, Tachida, H \& Yoshda T 2009 Molecular characterisation of cinnamon (Cinnamomum verum Presl) accessions and evaluation of genetic relatedness of cinnamon species in Sri Lanka based on trnL intron region, intergenic spacers between trnT-trnL, trnL-trnF, trnHpsbA and nuclear DNA ITS. Res. J. Agric. Biol. Sci. 5: 1079-1088.

Altschul S F, Madden T L, Schaffer A A, Zhang J, Zhang Z \& Miller W 1997 Gapped BLAST and PSI BLAST: A new generation of protein database search programs. Nucleic Acids Res. 25: 3389-3402.

Arunachalam K D \& Subhashini S 2011 Preliminary phytochemical investigation and wound healing activity of Myristica and Amanica leaves in Swiss albino mice. J. Med. Plants Res. 5: 1095-1106.

Bhagwat RM, Dholakia B B, Kadoo N Y, Balasundaran M \& Gupta V S 2015. Two new potential barcodes to discriminate Dalbergia species. PLoS ONE 10: e0142965.

Bieniek W, Mizianty M \& Szklarczyk M 2015 Sequence variation at the three chloroplast loci (matK, rbcL and psbA-trnH) in the Triticeae tribe (Poaceae): comments on the relationship and utility of DNA barcoding of selected species. Plant Syst. Evol. 301: 1275-1286. 
Bose T K, Maiti G G, Sanyal D, Sadhu, M K 2008 Dictionary of Horticulture Volume 7 Luzula-Ozothamnus, NayaUdyog, Kolkata. pp.4038-4043.

Edgar R C 2004 MUSCLE: multiple sequence alignment with high accuracy and high throughput. Nucleic Acids Res. 32: 17921797.

Gasteiger E, Gattiker A, Hoogland C, Ivanyi I, Appel R D \& Bairoch A 2003 ExPASy: the proteomics server for in-depth protein knowledge and analysis. Nucleic Acids Res. 31: 3784-3788.

Gielly L \& Taberlet P 1994 The use of chloroplast DNA to resolve plant phylogenies: Noncoding versus $r b c L$ sequences. Mol. Biol. Evol. 11: 769-777.

Hall T A 1999 Bioedit: A user-friendly biological sequence editor and analysis programme for Windows 95/98NT. Nucleic Acid Symp. 41: 95-98.

Hebert P D N, Cywinska A, Ball S L \& de Waard J R 2003 Biological identification through DNA barcodes. Proc. R .Soc. B. - Biol. Sci. 270: 313-321.

Hollingsworth P M 2011 Refining the DNA barcode for land plants. Proc. Natl. Acad. Sci. USA 108: 19451-19452.

Hooker J D \& Thomson T 1855 Flora India: Being a systematic account of the plants of British India together with observation on the structure and affinities of their natural order and genera, W. Pamplin, London. pp.155-164.

Hooker, J D 1856 Flora of British India Vol V Chenopodiaceae and Orchidaceae., Lovell Reeve \& Co Ltd, London. pp.102-113.

http://www.fao.org/docrep/x5047E/x5047E04.htm (accessed on 12 September 2019)

Huang X \& Madan A 1999 Cap 3: A DNA Sequence assembly program. Genome Res. 8: 868-877.

Kress J W, Wurdack K J, Zimmer E A, Weight L A \& Janzen D H 2005 Use of DNA barcodes to identify flowering plants. Proc. Natl. Acad. Sci. USA 102: 8369-8374.

Kress J W \& Erickson D L 2007 A two locus global DNA barcode for land plants: The coding $r b c L$ gene complements the non-coding $p s b A$ trnH region. PLoS ONE 6: e508.
Krishnamoorthy B, Rema J \& Mathew P A 2007 Tree spices. In: Peter K V \& Abraham Z (Eds.), Biodiversity in Horticultural Crops (pp.256277). Daya Publishing House, New Delhi.

Kück P \& Longo M 2014 FASconCAT-G: Extensive functions for multiple sequence alignment preparations concerning phylogenetic studies. Front. Zool. 11: 81.

Kumar S \& Yousuf A 2016 DNA barcoding and phylogenetic analysis of South Indian Curcuma species using chloroplast matK gene. Int. J. Adv. Res. 5: 615-621.

Li M, Wong K-L, Chan W-H, Li J-X, But PP-H, Cao H \& Shaw PC 2012 Establishment of DNA barcodes for the identification of the botanical sources of the Chinese 'cooling' beverage. Food Control 25: 758-766.

Li Y, Feng Y, Wang Xi-Y \& Lv G-H 2014 Failure of DNA barcoding in discriminating Calligonum species. Nord. J. Bot. 32: 511-517.

Liu Z, Chen S-L, Song J-Y, Zhang S-J \& Chen K-L 2012 Application of deoxyribonucleic acid barcoding in Lauraceae plants. Pharmacogn. Mag. 8: 04-11.

Manjunatha B K, Mankani K L, Mukunda S K R, Divakara R, Sridar B K \& Paul B K 2011 Antioxidant and hepato protective effect of Myristica malabarica seed aril extracts on carbon tetrachloride induced hepatic damage. Global J. Biotech. Biochem. 6: 25-30.

Mukherjee P \& Bhat K V 2013 Phylogenetic relationship of wild and cultivated yam species (Dioscorea spp.) of India inferred from PCR-RFLP analysis of two cpDNA loci. Plant Syst. Evol. 299: 1587-1597.

Ren B Q, Xiang X G \& Chen Z D 2010 Species identification of Alnus (Betulaceae) using nrDNA and cpDNA genetic markers. Mol. Ecol. Resour. 10: 594-605.

Ronquist F \& Huelsenbeck J P 2003 MrBayes 3: Bayesian phylogenetic inference under mixed models. Bioinformatics 19: 1572-1574.

Sastri B N 1962 The Wealth of India - A dictionary of Indian raw materials and industrial products Vol V- H-K, Council of Scientific and Industrial Research, New Delhi. pp.131-132.

Sauquet H, Doyle J A, Scharaschkin T, Borsch T, Hilu K W, Chatrou L W \& Thomas A L 2003 
Phylogenetic analysis of Magnoliales and Myristicaceae based on multiple data sets: implications for character evolution. Bot. J. Linn. Soc. 142: 125-186.

Schlling E E 1997 Phylogenetic analysis of Helianthes (Asteracecae) based on chloroplast DNA restriction site data. Theor. Appl. Genet. 94: 925-933.

Sinclair J 1958 Flora Malesiana precursors XL II, the genus Myristica in Malaysia and outside Malaysia, pp.1-540.

Schneider S C, Rodrigues A, Moe T F \& Ballot A 2015 DNA barcoding the genus Chara: molecular evidence recovers fewer taxa than the classical morphological approach. J. Phycol. 51: 367-380.

Sheeja T E, George K J, Jerome J, Varma R S, Syamkumar S, Krishnamoorthy B \& Parthasarathy V A 2008 Optimisation of DNA isolation and PCR parameters in Myristica sp. and related genera for RAPD and ISSR analysis. J. Spices Arom. Crops 17: 91-97.

Sheeja T E, Rosana O B, Swetha V P, Shalini R S, Siju S, Dhanya R, Rahul P R \& Krishnamoorthy B 2014 The 18S rDNA gene discriminates between red-listed and unexplored ethnomedicinal species of Myristicaceae restricted to humid tropics of India. Genet. Resour. Crop Ev. 61: 523-535.

Simeone M C, Piredda R, Papini A, Vessella F \& Schirone B 2013 Application of plastid and nuclear markers to DNA barcoding of Euro
- Mediterranean oaks (Quercus, Fagaceae): problems, prospects and phylogenetic implications. Bot. J. Linn. Soc. 172: 478-499.

Souframanien J \& Gopalakrishnan T A 2004 A comparative analysis of genetic diversity in blackgram genotypes using RAPD and ISSR markers. Theor. Appl. Genet. 109: 1687-1693.

Swetha V P, Parvath V A, Sheeja T E \& Sasikumar B 2017 Authentication of Myristica fragrans Houtt using DNA bardoding. Food Control 74: 1010-1015.

Tallei T E \& Kolondam B J 2015 DNA barcoding of Sangihe nutmeg (Myristica fragrans) using matK gene. HAYATI J. Biosci. 22: 41-47.

Vijayan K \& Tsou C H 2010 DNA barcoding in plants: taxonomy in a new perspective. Curr. Sci. 99: 1530-1541.

Yang Y, Zhai Y, Liu T, Zhang F \& Ji Y 2011 Detection of Valeriana jatamansi as an adulterant of medicinal Paris by length variation of chloroplast. Planta Med. 77: 87-91.

Zachariah T J, Leela N K, Maya K M, Rema J, Mathew P A, Vipin T M \& Krishnamoorthy B 2008 Chemical composition of leaf oils of Myristica beddomei (King), Myristica fragrans Houtt. and Myristica malabarica (Lamk.). J. Spices Arom. Crops 17: 10-15.

Zhang J, Chen M, Dong X, Lin R, Fan J \& Chen Z 2015 Evaluation of four commonly used DNA barcoding loci for Chinese medicinal plants of the family Schisandraceae. PLoS ONE 10: e0125574. 